\title{
Article
}

Doi 10.5943/sif/5/1/14

\section{Antibacterial activities of mangrove leaf endophytic fungi from Luzon Island, Philippines}

\author{
Ramirez $\mathrm{CSP}^{1,2}$, Notarte $\mathrm{KIR}^{2}$ and dela Cruz TEE $\mathrm{TE}^{1,2,3^{*}}$
}

\author{
${ }^{1}$ The Graduate School, University of Santo Tomas, España Blvd. 1008 Manila, Philippines \\ ${ }^{2}$ Fungal Biodiversity, Ecogenomics and Systematics Group, Research Center for the Natural and Applied Sciences, \\ University of Santo Tomas, España Blvd. 1008 Manila, Philippines \\ ${ }^{3}$ Department of Biological Sciences, College of Science, University of Santo Tomas, España Blvd. 1008 Manila, \\ Philippines
}

Ramirez CSP, Notarte KIR, dela Cruz TEE 2020 - Antibacterial activities of mangrove leaf endophytic fungi from Luzon Island, Philippines. Studies in Fungi 5(1), 320-331, Doi 10.5943/sif/5/1/14

\begin{abstract}
Fungi associated with mangroves are untapped sources of bioactive secondary metabolites. In this study, 628 mangrove leaf endophytic fungi (MLEF) were recorded from 19 mangrove hosts collected from the provinces of Zambales, Batangas, Cavite, and Quezon in Luzon Island, Philippines. The MLEF morphospecies were identified as belonging to the genera Aspergillus, Cladosporium, Colletotrichum, Fusarium, Nigrospora, Penicillium, Pestalotiopsis, Phialophora, and Trichoderma. Screening revealed that the MLEF crude culture extracts were promisingly potent against the gram-positive bacteria Staphylococcus aureus and Micrococcus luteus (ZOI > 19 $\mathrm{mm}$ ) with no or partial activity against the gram-negative bacteria Klebsiella oxytoca and Pseudomonas aeruginosa. Our findings showed that mangrove leaf endophytic fungi are potential sources of bioactive compounds.
\end{abstract}

Key words - bioactivities - fungal endophytes - mangrove forests - secondary metabolites

\section{Introduction}

Mangroves are hosts to many plant-associated microorganisms including fungi. The diversity of these mangrove-associated fungi, also known as manglicolous fungi, is influenced by numerous factors such as wide variety of substrates and level of salinity (Zhou et al. 2018). In the Philippines, studies have recently reported the isolation of fungal endophytes from mangrove leaves (Guerrero et al. 2018, Moron et al. 2018, Apurillo et al. 2019). Still, limited studies on fungal endophytes associated with Philippine mangroves have been done despite the numerous species of mangroves present in the country. Of the 65 species of mangroves known worldwide and of the 60 mangrove species found in the Indo-Pacific region, around 40 species inhabit the Philippines (Primavera 2000). However, overexploitation and conversion of mangrove forests to fishponds and human settlements have caused a steep decline in Philippine mangroves with about $70 \%$ habitat loss since 1951 (Primavera 2000). With the continued decline in the mangrove habitat, it is imperative to study the mangrove mycoflora in the Philippines before the loss of the available mangrove habitats becomes permanent.

Interestingly, the marine environment is tapped for the search for microorganisms capable of producing biologically active natural products. Marine-associated fungi have been shown to 
produce secondary metabolites with anti-infective properties (Schulz et al. 2008, Lavadia et al. 2017, Notarte et al. 2017, 2018). Fungi from mangroves have also been tapped for their biological activities including anticancer compounds (Tan et al. 2015, Deshmukh et al. 2018, Moron et al. 2018, Apurillo et al. 2019). For example, the mangrove fungus Diaporthe produced the polyketide dicerandrol D that displayed a selective antimalarial activity (Calcul et al. 2013). In another study, the antiviral fumiquinazoline alkaloids neosartoryadins A and B were isolated from the mangrove fungus Neosartorya udagawae (Yu et al. 2016). The mangrove fungal endophyte Penicillium chrysogenum was found to produce an antibacterial compound containing an indole and a diketopiperazine moiety which was active against Vibrio cholerae (Devi et al. 2012). Tan et al. (2015) identified tyrosol C, cytosporone B, dothiorelone A, and dothiorelone C from culture extracts of Phyllosticta sp., an endophytic fungus identified from Philippine mangroves. With the emergence of new diseases due to factors such as agricultural changes, population growth, global migration, and the occurrence of antibiotic-resistant disease-causing microbes, it is vital to search for new sources of drugs. Interestingly, the mangroves in the Philippines are potential reservoir of highly diversified endophytic fungi that may have unique metabolic properties. Thus, in this study, the endophytic fungi were isolated from mangrove leaves collected from Batangas, Cavite, Quezon, and Zambales and screened for their antibacterial properties.

\section{Materials \& Methods}

\section{Identification of host mangroves}

The vegetative and reproductive parts of healthy mangroves were collected from the coastal areas of Zambales, Batangas, Cavite and Quezon (Table 1). Herbaria of the mangrove samples were then prepared by mounting pressed, oven-dried specimens (branch, leaves, fruits, flowers) onto clean bristol board. Identification of the collected mangrove species was done following comparison of their morphology with published identification guides/keys, e.g. Primavera (2009) and Calumpong \& Meñez (1997). Herbarium specimens were also sent to the Botany Division, National Museum in Manila for species identification and verification.

\section{Isolation of mangrove leaf endophytic fungi}

Healthy leaf samples from 19 mangrove hosts were transported to the laboratory in clean ziplocked plastic bags and processed within $24 \mathrm{~h}$ of collection. The mangrove leaves were initially washed with cold, running tap water to remove any soil debris and then dried with clean paper towels. The leaf samples were hole-punched (6 $\mathrm{mm}$ in diameter) using a flame-sterilized puncher and collected into sterile petri dishes. The leaf explants (30 explants per mangrove species per collection site) were then surface sterilized following the protocol of Toofanee \& Dulymamode (2002). This was done by immersing the leaf explants in 75\% ethyl alcohol (Univar) for 1 min, followed by $0.5 \%$ sodium hypochlorite solution for $3 \mathrm{~min}$, and then, in $75 \%$ ethyl alcohol for an additional $30 \mathrm{sec}$. Hereafter, the explants were washed three times with sterile artificial seawater (ASW, $33 \mathrm{~g}$ commercially available marine salt dissolved in 1,000 mL distilled water). Following surface-sterilization, the leaf explants (6 leaf explants per culture plate) were placed on culture plates pre-filled with 2\% Malt Extract Agar (Oxoid) supplemented with $33 \mathrm{~g} / \mathrm{L}$ marine salt (Bioresearch) and $500 \mathrm{mg} / \mathrm{L}$ streptomycin sulphate (Sigma). A total of 5 plates were inoculated for each host plant species. All culture plates were then incubated at room temperature $\left(25 \pm 2{ }^{\circ} \mathrm{C}\right)$ for 1-4 weeks. The fungi that grew out of the leaf explants were cut out and transferred to freshly prepared Potato Dextrose Agar (PDA, Pronadisa) plates supplemented with $33 \mathrm{~g} / \mathrm{L}$ marine salt (PDAS) for purification.

\section{Identification of mangrove leaf endophytic fungi}

The isolated mangrove leaf endophytic fungi were initially cultured on freshly prepared PDAS plates and incubated at room temperature for 3-5 days. The fungal colonies were then described based on their colony appearance, e.g. texture, margin, color, reverse texture, and reverse 
color. For the spore and hyphal morphology of the isolated MLEF, spores and hyphae were fixed with lactophenol in clean glass slides and viewed under a compound light microscope (Olympus model, 400-1000x) (Henrici 1930). Spore color, shape, and arrangement as well as hyphal morphology were noted. Identification of the isolated endophytic fungi was done based on published literature (Samson et al. 2010).

Table 1 The sampling localities for the collection of host mangroves.

\begin{tabular}{|c|c|c|c|}
\hline Province & Collection sites & GPS coordinates & Host mangrove species \\
\hline \multirow{8}{*}{$\begin{array}{l}\frac{\mathscr{U}}{\tilde{N}} \\
\stackrel{\text { IJ }}{\text { N }}\end{array}$} & San Agustin, Iba & $\begin{array}{l}\mathrm{N} 15^{\circ} 11^{\prime} 26.3^{\prime \prime} \\
\mathrm{E} 119^{\circ} 57^{\prime} 12.3^{\prime \prime}\end{array}$ & $\begin{array}{l}\text { Avicennia marina (Forssk.) Vierh. } \\
\text { Excoercaria agallocha L. } \\
\text { Nypa fruticans Wurmb. } \\
\text { Sonneratia alba J. Smith } \\
\text { Xylocarpus granatum Koen }\end{array}$ \\
\hline & Felmida Diaz, Cabangan & $\begin{array}{l}\mathrm{N} 15^{\circ} 11^{\prime} 26.3^{\prime \prime} \\
\mathrm{E} 120^{\circ} 01^{\prime} 53.7^{\prime \prime}\end{array}$ & Rhizophora mucronata Poir. \\
\hline & Libaba, Palauig & $\begin{array}{l}\mathrm{N} 15^{\circ} 26^{\prime} 05.7^{\prime \prime} \\
\mathrm{E} 119^{\circ} 53^{\prime} 47.2^{\prime \prime}\end{array}$ & $\begin{array}{l}\text { A. marina } \\
\text { R. mucronata }\end{array}$ \\
\hline & Lipay, Palauig & $\begin{array}{l}\mathrm{N} 15^{\circ} 29^{\prime} 07.6^{\prime \prime} \\
\mathrm{E} 119^{\circ} 54^{\prime} 17.1^{\prime \prime}\end{array}$ & $\begin{array}{l}\text { A. marina } \\
\text { R. mucronata } \\
\text { S. alba }\end{array}$ \\
\hline & Banban, Masinloc & $\begin{array}{l}\mathrm{N}^{\circ} 5^{\circ} 30^{\prime} 21.3^{\prime \prime} \\
\mathrm{E} 19^{\circ} 58^{\prime} 06.8^{\prime \prime}\end{array}$ & $\begin{array}{l}\text { Osbornia octodonta F. Muell. } \\
\text { R. mucronata }\end{array}$ \\
\hline & Taltal, Masinloc & $\begin{array}{l}\mathrm{N} 15^{\circ} 34^{\prime} 07.0^{\prime \prime} \\
\mathrm{E} 119^{\circ} 57^{\prime} 03.9^{\prime \prime}\end{array}$ & $\begin{array}{l}\text { A. marina } \\
\text { R. mucronata } \\
\text { S. alba }\end{array}$ \\
\hline & Uacon, Candelaria & $\begin{array}{l}\mathrm{N} 15^{\circ} 40^{\prime} 17.4^{\prime \prime} \\
\mathrm{E} 119^{\circ} 56^{\prime} 11.7^{\prime \prime}\end{array}$ & $\begin{array}{l}\text { Aegiceras floridum Roem. \& Schult. } \\
\text { A. marina } \\
\text { R. mucronata } \\
\text { S. alba }\end{array}$ \\
\hline & Subic Bay, Olongapo & $\begin{array}{l}\mathrm{N} 14^{\circ} 46^{\prime} 56.9^{\prime \prime} \\
\mathrm{E} 120^{\circ} 16^{\prime} 58.5^{\prime \prime}\end{array}$ & $\begin{array}{l}\text { A. marina } \\
\text { S. alba }\end{array}$ \\
\hline \multirow{2}{*}{ 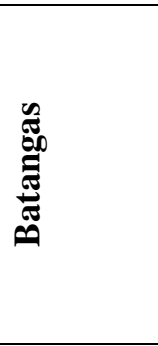 } & Wawa, Nasugbu & $\begin{array}{l}\mathrm{N} 14^{\circ} 05^{\prime} 12.1^{\prime \prime} \\
\mathrm{E} 120^{\circ} 37^{\prime} 20.4^{\prime \prime}\end{array}$ & $\begin{array}{l}\text { Acanthus ebracteatus Vahl. } \\
\text { A. marina } \\
\text { Ceriops tagal (Perr.) C.B. Robinson } \\
\text { R. mucronata } \\
\text { S. alba }\end{array}$ \\
\hline & Lian & $\begin{array}{l}\mathrm{N} 13^{\circ} 56^{\prime} 39.3^{\prime \prime} \\
\mathrm{E} 120^{\circ} 36^{\prime} 50.9^{\prime \prime}\end{array}$ & $\begin{array}{l}\text { A. marina } \\
\text { R. mucronata } \\
\text { S. alba }\end{array}$ \\
\hline نั & Maragondon & $\begin{array}{l}\text { N14 } 14^{\circ} 13^{\prime} 07.7^{\prime \prime} \\
\text { E120 } 37^{\prime} 14.2^{\prime \prime}\end{array}$ & $\begin{array}{l}\text { A. marina } \\
\text { R. mucronata } \\
\text { S. alba }\end{array}$ \\
\hline \multirow{4}{*}{ 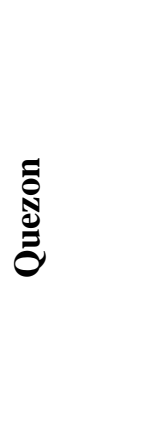 } & Gumaca & $\begin{array}{l}\mathrm{N} 13^{\circ} 55^{\prime} 02.3^{\prime \prime} \\
\mathrm{E} 122^{\circ} 07^{\prime} 31.7^{\prime \prime}\end{array}$ & $\begin{array}{l}\text { A. marina } \\
\text { S. alba }\end{array}$ \\
\hline & Calauag & $\begin{array}{l}\mathrm{N} 13^{\circ} 57^{\prime} 37.1^{\prime \prime} \\
\mathrm{E} 122^{\circ} 17^{\prime} 23.0^{\prime \prime}\end{array}$ & $\begin{array}{l}\text { A. marina } \\
\text { R. mucronata }\end{array}$ \\
\hline & San Narciso & $\begin{array}{l}\mathrm{N} 13^{\circ} 33^{\prime} 49.6^{\prime \prime} \\
\mathrm{E} 122^{\circ} 34^{\prime} 49.8^{\prime \prime}\end{array}$ & $\begin{array}{l}\text { A. marina } \\
\text { R. stylosa } \\
\text { S. alba }\end{array}$ \\
\hline & Unisan & $\begin{array}{l}\mathrm{N} 13^{\circ} 49^{\prime} 48.2^{\prime \prime} \\
\mathrm{E} 121^{\circ} 58^{\prime} 48.1^{\prime \prime}\end{array}$ & $\begin{array}{l}\text { A. marina } \\
\text { R. mucronata } \\
\text { S. alba }\end{array}$ \\
\hline
\end{tabular}


Table 1 Continued.

\begin{tabular}{|c|c|c|c|}
\hline Province & Collection sites & GPS coordinates & Host mangrove species \\
\hline 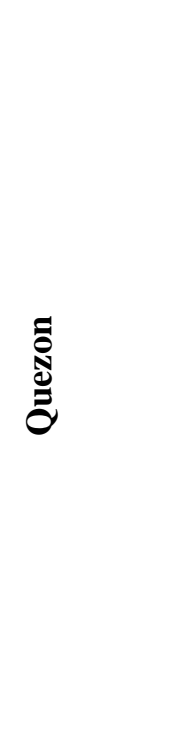 & Pagbilao & $\begin{array}{l}\mathrm{N} 13^{\circ} 58^{\prime} 31.5^{\prime \prime} \\
\mathrm{E} 121^{\circ} 43^{\prime} 32.4^{\prime \prime}\end{array}$ & $\begin{array}{l}\text { A. ebracteatus } \\
\text { Aegiceras corniculatum (L.) Blanco } \\
\text { A. floridum } \\
\text { Avicennia officinalis L. } \\
\text { A. marina } \\
\text { Brugueira sp. } \\
\text { B. sexangular } \\
\text { Camptostemon philippinense (Vidal) Becc. } \\
\text { Ceriops decandra (Griff.) Ding Hou } \\
\text { C. tagal } \\
\text { E. agallocha } \\
\text { O. octodonta } \\
\text { Rhizophora apiculata Blume } \\
\text { R. mucronata } \\
\text { R. stylosa } \\
\text { Scyphiphora hydrophyllacea C.F. Gaertn. } \\
\text { S. alba } \\
X \text {. granatum }\end{array}$ \\
\hline
\end{tabular}

To determine the ability of 19 representative fungi to grow in the presence and absence of marine salts, an agar block approximately $5 \mathrm{~mm}^{2}$ were cut from the 7-day old MLEF and inoculated onto PDA and PDAS in triplicates. Culture plates were then incubated at room temperature. Colony radial growth was then measured for each of the isolates as the distance from the agar block to the margin of the growing fungal colony using a standard ruler. Two readings per plate were recorded on the $4^{\text {th }}$ and $6^{\text {th }}$ day to coincide with growths of both slow and fast-growing fungi. The colony extension rates (CER) were determined using the equation described by Notarte et al. (2017): CER $=$ [length of hyphal growth after 6 incubation days $\left(\mathrm{d}_{\mathrm{f}}\right)$ ] - [length of hyphal growth after 4 incubation days $\left.\left(\mathrm{d}_{\mathrm{i}}\right)\right] / 2$. To test for significant differences between the colony extension rates of the MLEF, one-way ANOVA was computed using SigmaStat ver.3.1 (Systat Software, USA).

\section{Production and extraction of secondary metabolites from mangrove leaf endophytic fungi}

Selected 17 mangrove leaf endophytic fungi were grown in PDAS slants for one week. Following incubation, spore and mycelial suspensions were prepared by adding $5 \mathrm{~mL}$ sterile distilled water on the culture slants. Then, the spore and mycelial suspensions were transferred into $100 \mathrm{~mL}$ Potato Dextrose Broth (PDB, Pronadisa) supplemented with $33 \mathrm{~g} / \mathrm{L}$ marine salt (in duplicates) and incubated under static condition at room temperature for 3-4 weeks. After incubation, $100 \mathrm{~mL}$ ethyl acetate (RCI Labscan) was added to each culture bottle and soaked overnight. After $24 \mathrm{~h}$, the fungal mycelia were filtered in filter paper and the ethyl acetate extracts were decanted. The culture filtrates per MLEF were combined and concentrated in vacuo at $35^{\circ} \mathrm{C}$ using a rotary evaporator. The crude culture extracts were transferred to pre-weighed amber bottles and allowed to dry. Then, the crude culture extracts were finally dissolved in methanol:acetone (1:1 $\mathrm{v} / \mathrm{v}$ ) to a final concentration of $100 \mathrm{mg} / \mathrm{mL}$, and then stored inside the refrigerator until used in the assay.

\section{Assay for the antibacterial activities}

Standard test bacteria, Klebsiella oxytoca (ATCC 700524), Micrococcus luteus (environmental sample), Pseudomonas aeruginosa (ATCC 27853) and Staphylococcus aureus (ATCC 25923), were acquired from the University of Santo Tomas Collection of Microbial Strains, Manila, Philippines. These bacteria were selected because of their pathogenicity. Initially, these bacteria were maintained and stored on Nutrient Agar (NA, HiMedia) plates. Prior to the assay, the test bacteria were grown on NA plates for $24 \mathrm{~h}$. Following incubation, cell suspension was prepared 
with sterile normal saline solution. The cell concentration was adjusted to 0.5 McFarland and then swabbed using sterile cotton swab onto culture plates pre-filled with $25 \mathrm{~mL}$ Mueller Hinton Agar (MHA, HiMedia). Due to insufficiency of the extracted metabolites in some species, 10 to $30 \mu \mathrm{L}$ of the stock crude culture extracts $(100 \mathrm{mg} / \mathrm{mL}$ ) were added onto sterile paper disks (Whatman, $6 \mathrm{~mm}$ in diameter) giving a final concentration of 1-3 mg of extract per disk. The impregnated disks were then air-dried and placed onto the inoculated culture plates (in triplicates). As positive control for $K$. oxytoca, $M$. luteus, $P$. aeruginosa, and $S$. aureus, commercially available standard antibiotic disks containing $10 \mu \mathrm{g} / \mathrm{mL}$ streptomycin (BBL) and $30 \mu \mathrm{g} / \mathrm{mL}$ tetracycline (BBL) were used in the assay. The solvent methanol:acetone was used as negative control. All culture plates were then incubated at $37^{\circ} \mathrm{C}$ for $24 \mathrm{~h}$. After incubation, zones of inhibition (ZOI) were measured using a ruler and their antimicrobial activities were assessed using the following indices: (1) very active: $>19$ mm ZOI, (2) active: 13-19 mm ZOI, (3) partially active: 10-12 mm ZOI, and (4) inactive: $<10 \mathrm{~mm}$ ZOI (Quinto \& Santos 2005).

\section{Results}

\section{The fungal endophytes associated with mangrove leaves}

A total of 628 fungal isolates belonging to 20 different morphospecies were recorded from the 19 mangrove hosts that were collected from the provinces of Zambales, Batangas, Cavite and Quezon in Luzon Island, Philippines (Table 2). Morphocultural characterization identified the MLEF as belonging to the genera Aspergillus, Cladosporium, Colletotrichum, Pestalotiopsis, Phialophora, Trichoderma, Fusarium, Nigrospora, and Penicillium. Two MLEF, however, were not identified by morphological methods and were labelled only as morphospecies 1 and morphospecies 2. One MLEF remained sterile even after prolonged incubation and was designated as mycelia sterilia.

Though the isolated mangrove leaf endophytic fungi were similar to known terrestrial fungal genera, 19 representative MLEF were tested for their growth in the absence or presence of marine salts (Fig. 1). Some of these selected MLEF were similar morphospecies but isolated from different localities. Results showed that some of the MLEF (Nigrospora sp. 2, Penicillium sp. 1, Penicillium sp. 3, Penicillium sp. 4, Penicillium sp. 5 and mycelia sterilia) grew significantly better in the presence of marine salts than in PDA without marine salts $(p<0.01)$. Interestingly, Nigrospora sp. 1 isolated from $R$. mucronata leaves collected from Batangas and Quezon showed varied growth patterns in PDA with and without marine salts. Nigrospora sp. 1 from Batangas demonstrated faster growth as compared to the same morphospecies from Quezon regardless of the presence of salt. The ability of MLEF to grow in the presence of marine salts indicated their possible adaptation in the marine habitat.

\section{Production of antibacterial metabolites from mangrove leaf endophytic fungi}

Seventeen selected MLEF isolates were extracted for their secondary metabolites and tested for their biological properties. These fungi were commonly isolated and exhibited unique colonial morphology and/or produced pigment in culture media. We have also chosen different fungal strains of the same morphospecies that were isolated either from different host mangroves and/or collection sites. Interestingly, the MLEF showed to be more biologically active against grampositive than gram-negative bacteria (Table 3). Of the $17 \mathrm{MLEF}$, four isolates (Phialophora, Cladosporium, Penicillium sp.4 and Penicillium sp.5) were very active ( $>19 \mathrm{~mm}$ ZOI) against $S$. aureus. Aside from targeting S. aureus, eight MLEF isolates (Phialophora, Cladosporium, Penicillium sp.3, Penicillium sp.4 and Penicillium sp.5) were also very potent against M. luteus (>19mm ZOI). Among these bioactive MLEF, Phialophora spp. isolated from different host mangroves showed varied biological activities. Phialophora sp. derived from Sonneratia alba showed very active antibacterial property against $S$. aureus (22 $\mathrm{mm} \mathrm{ZOI)} \mathrm{and} \mathrm{M.} \mathrm{luteus} \mathrm{(32} \mathrm{mm}$ ZOI), while Phialophora sp. isolated from Rhizophora mucronata showed no antagonism to the same pathogens. 
Table 2 Number of mangrove leaf endophytic fungi isolated from 19 mangrove species.

\begin{tabular}{|c|c|c|c|c|c|c|c|c|c|c|c|c|c|c|c|c|c|c|c|}
\hline \multirow[b]{2}{*}{$\begin{array}{l}\text { Mangrove Leaf } \\
\text { Endophytic Fungi } \\
\text { (MLEF) }\end{array}$} & \multicolumn{19}{|c|}{ Host Mangroves } \\
\hline & 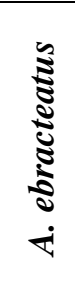 & 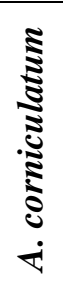 & 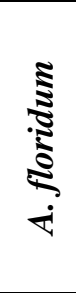 & $\begin{array}{l}\mathfrak{\Xi} \\
\stackrel{\Xi}{\Xi} \\
\mathfrak{\Xi} \\
\dot{\Sigma}\end{array}$ & 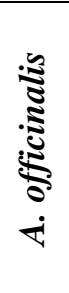 & 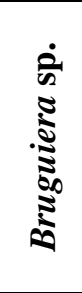 & 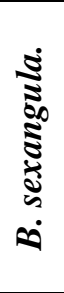 & 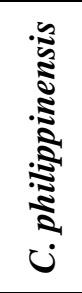 & 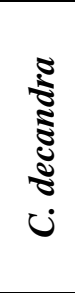 & 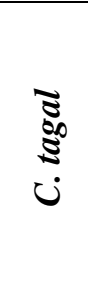 & 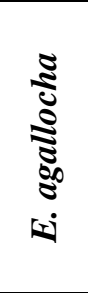 & $\underset{z}{\tilde{Z}}$ & 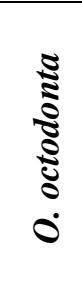 & 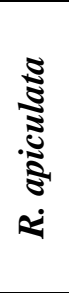 & 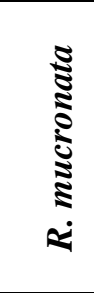 & 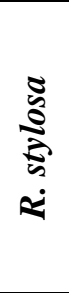 & 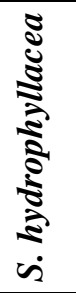 & 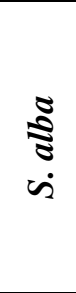 & 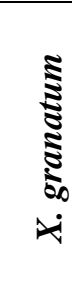 \\
\hline A. niger & - & - & - & 19 & 1 & - & - & - & 6 & 6 & - & - & - & - & - & - & - & 3 & - \\
\hline A. ochraceus & 3 & - & - & 5 & - & - & - & - & - & - & - & - & - & - & - & - & - & 14 & 6 \\
\hline Cladosporium sp. & - & 1 & 11 & 6 & - & - & - & - & 1 & 1 & - & 1 & - & - & 13 & 2 & - & 11 & - \\
\hline Colletotricum sp. & 12 & - & - & 4 & - & 11 & - & - & - & - & - & - & - & - & 2 & - & - & - & - \\
\hline Fusarium sp. 1 & - & - & - & - & - & - & - & - & - & - & - & - & - & - & 2 & - & - & 1 & - \\
\hline Fusarium sp. 2 & - & - & - & - & - & - & - & - & - & - & - & - & - & - & 3 & - & - & - & - \\
\hline Morphospecies 1 & - & - & - & 2 & - & - & - & - & - & - & - & - & - & - & 1 & - & - & - & - \\
\hline Morphospecies 2 & - & - & - & - & - & - & - & - & - & - & - & - & - & 2 & - & - & - & - & - \\
\hline Mycelia sterilia & 1 & - & 1 & 31 & 4 & 15 & 1 & 30 & 9 & 9 & - & - & 9 & 5 & 28 & 4 & - & 9 & 10 \\
\hline Nigrospora sp. 1 & - & - & - & 1 & - & - & - & - & - & - & - & 2 & - & - & 4 & - & - & 8 & - \\
\hline Nigrospora sp. 2 & 1 & 2 & - & 20 & - & - & - & - & - & - & - & - & - & - & - & 1 & - & 3 & - \\
\hline Penicillium sp. 1 & - & - & - & - & - & - & - & - & - & - & 27 & - & 2 & - & - & - & - & - & - \\
\hline Penicillium sp. 2 & - & - & 1 & - & - & - & - & - & - & - & - & - & - & - & - & - & - & 1 & - \\
\hline Penicillium sp. 3 & - & - & - & - & - & - & - & - & 13 & 13 & - & - & - & - & - & - & - & 5 & - \\
\hline Penicillium sp. 4 & - & - & - & 11 & - & - & - & - & - & - & 8 & - & - & - & 29 & - & - & 2 & - \\
\hline Penicillium sp. 5 & - & - & - & - & - & - & - & - & - & - & 19 & - & - & - & 2 & - & - & 1 & - \\
\hline Penicillium sp. 6 & - & - & - & 10 & - & - & - & - & - & - & - & - & - & - & - & - & - & - & - \\
\hline Pestalotiopsis sp. & - & - & - & 3 & - & - & - & - & - & - & - & 1 & - & - & 5 & - & - & - & - \\
\hline Phialophora sp. & 9 & - & 1 & 10 & 4 & - & - & - & 4 & 4 & 31 & 8 & 11 & - & 12 & 1 & - & 15 & 4 \\
\hline Trichoderma sp. & - & - & - & - & - & - & - & - & - & - & - & - & - & - & 3 & - & - & - & - \\
\hline Subtotal & 26 & 3 & 14 & 122 & 9 & 26 & 1 & 30 & 33 & 33 & 85 & 12 & 22 & 7 & 104 & 8 & 0 & 73 & 20 \\
\hline Total & & & & & & & & & & 628 & & & & & & & & & \\
\hline
\end{tabular}




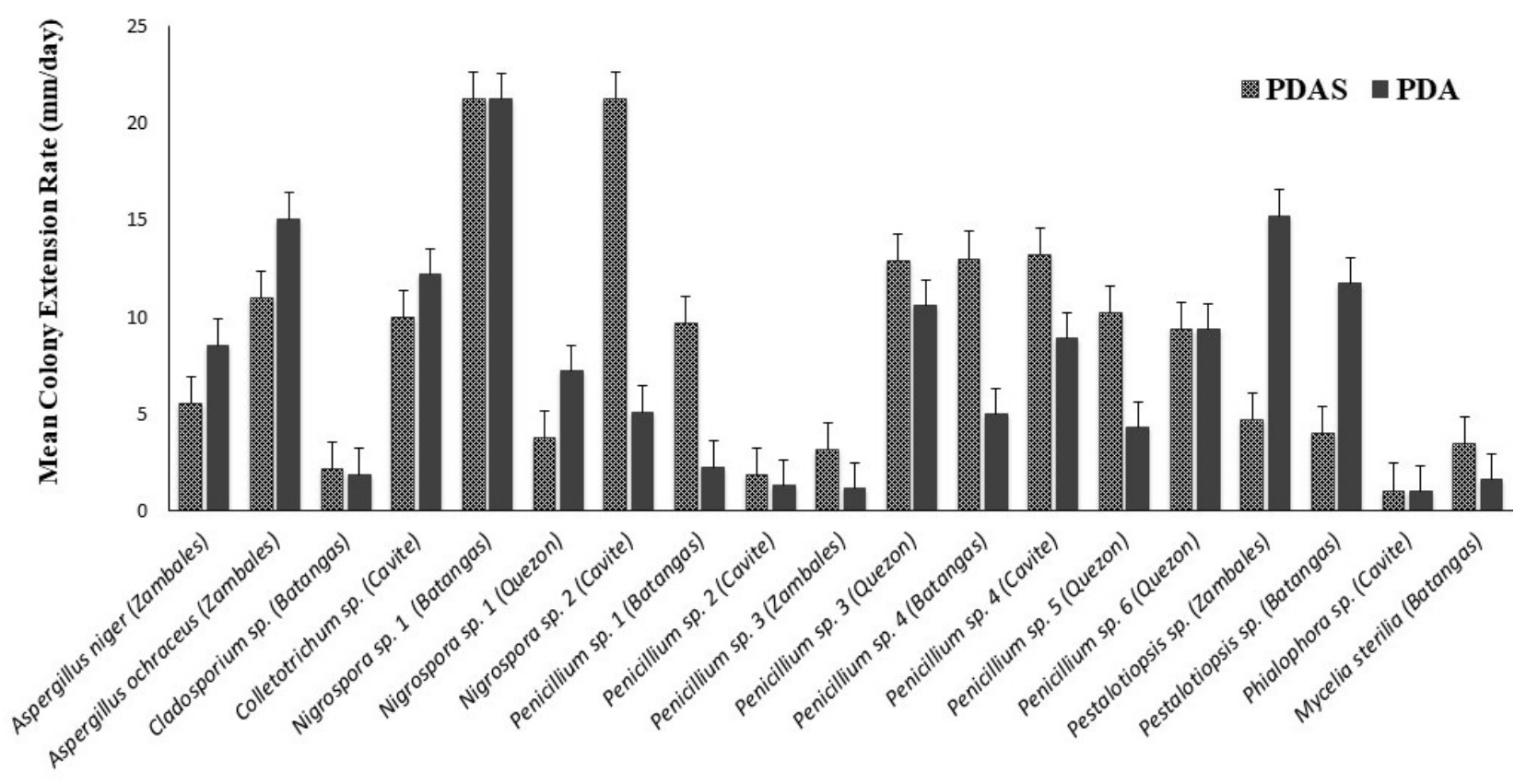

Fig. 1 - Mean colony extension rates (in mm/day) of MLEF isolates grown on PDA in the absence or presence of marine salts. Standard error of the mean was presented in error bars $(p<0.01)$.

Another interesting finding showed that the crude culture extracts from Phialophora sp. (22$32 \mathrm{~mm}$ ZOI), Cladosporium sp. (16-34 mm ZOI), Penicillium sp.4 (15-42 mm ZOI) and Penicillium sp.5 (20 mm ZOI) showed comparable or even more potent antibacterial property than the antibiotic controls streptomycin (11-25 ZOI) and tetracycline (22-40 ZOI) against S. aureus and $M$. luteus. The differences between the zones of inhibition exhibited by the MLEF crude culture extracts were found to be statistically significant $(p<0.001)$. In contrast to the potency of the culture extracts against gram-positive bacteria, the MLEF showed partial activity or no antagonism to the gram-negative bacteria $P$. aeruginosa and K. oxytoca.

Table 3 Antibacterial properties of mangrove leaf endophytic fungi against gram-positive and gram-negative bacteria $(n=3)$.

\begin{tabular}{|c|c|c|c|c|c|c|}
\hline \multirow{2}{*}{ Province } & \multirow{2}{*}{ Host Mangrove } & \multirow{2}{*}{$\begin{array}{l}\text { Fungal } \\
\text { Endophytes }\end{array}$} & \multicolumn{4}{|c|}{$\begin{array}{l}\text { Test bacteria zone of inhibition, ZOI } \\
(\mathbf{m m} \pm \mathrm{SD})^{\mathrm{a}}\end{array}$} \\
\hline & & & $\begin{array}{l}\text { S. } \\
\text { aureus }\end{array}$ & $\begin{array}{l}P . \\
\text { aeruginosa }\end{array}$ & $\begin{array}{l}\text { K. } \\
\text { oxytoca }\end{array}$ & $\begin{array}{l}\text { M. } \\
\text { luteus }\end{array}$ \\
\hline \multirow{6}{*}{ Zambales } & Sonneratia alba & Phialophora sp. & $22 \pm 0$ & - & - & $32 \pm 0$ \\
\hline & Rhizophora mucronata & Phialophora sp. & - & - & - & - \\
\hline & Xylocarpus granatum & A. ochraceus & $8 \pm 0$ & - & - & $10 \pm 0$ \\
\hline & Avicennia marina & Cladosporium sp. & $21 \pm 0$ & - & - & $30 \pm 0$ \\
\hline & Sonneratia alba & Cladosporium sp. & $16 \pm 0$ & - & - & $34 \pm 2.3$ \\
\hline & Sonneratia alba & Penicillium sp. 2 & $9 \pm 0$ & - & - & $12 \pm 0$ \\
\hline \multirow{6}{*}{ Batangas } & Avicennia marina & A. niger & $7 \pm 0$ & - & $9 \pm 0$ & $13 \pm 0.6$ \\
\hline & Avicennia marina & A. ochraceus & - & - & - & $8 \pm 0.6$ \\
\hline & Acanthus ebracteatus & A. ochraceus & - & - & - & $8 \pm 0$ \\
\hline & Sonneratia alba & Penicillium sp. 4 & $20 \pm 0$ & - & $10 \pm 0$ & $35 \pm 0$ \\
\hline & Avicennia marina & Penicillium sp. 4 & $15 \pm 0$ & - & - & $42 \pm 0$ \\
\hline & Sonneratia alba & Penicillium sp. 5 & $20 \pm 0$ & - & - & $20 \pm 0$ \\
\hline Cavite & Rhizophora mucronata & Penicillium sp. 4 & $18 \pm 0$ & - & $7 \pm 0$ & $35 \pm 0$ \\
\hline
\end{tabular}


Table 3 Continued.

\begin{tabular}{|c|c|c|c|c|c|c|}
\hline \multirow{2}{*}{ Province } & \multirow{2}{*}{ Host Mangrove } & \multirow{2}{*}{$\begin{array}{l}\text { Fungal } \\
\text { Endophytes }\end{array}$} & \multicolumn{4}{|c|}{$\begin{array}{l}\text { Test bacteria zone of inhibition, ZOI } \\
(\mathbf{m m} \pm S D)^{\mathrm{a}}\end{array}$} \\
\hline & & & $\begin{array}{l}\text { S. } \\
\text { aureus }\end{array}$ & $\begin{array}{l}P . \\
\text { aeruginosa }\end{array}$ & $\begin{array}{l}\text { K. } \\
\text { oxytoca }\end{array}$ & $\begin{array}{l}\text { M. } \\
\text { luteus }\end{array}$ \\
\hline \multirow{4}{*}{ Quezon } & Osbornia octodonta & Penicillium sp. 1 & $18 \pm 0$ & - & - & $16 \pm 0$ \\
\hline & E. agallocha & Penicillium sp. 1 & - & - & & $13 \pm 0.6$ \\
\hline & Sonneratia alba & Penicillium sp. 4 & $15 \pm 1.2$ & - & - & $33 \pm 0$ \\
\hline & Sonneratia alba & Mycelia sterilia & - & - & - & $14 \pm 1.7$ \\
\hline \multirow{3}{*}{ Controls } & Negative & MeOH: Acetone & - & - & - & - \\
\hline & & Streptomycin & $11 \pm 0$ & $13 \pm 0$ & $24 \pm 0$ & $25 \pm 0$ \\
\hline & Positive & Tetracycline & $22 \pm 0.6$ & $11 \pm 0$ & $22 \pm 0$ & $40 \pm 0$ \\
\hline
\end{tabular}

aOI: inactive $<10 \mathrm{~mm}$, partially active $10-13 \mathrm{~mm}$, active $14-19 \mathrm{~mm}$, very active $>19 \mathrm{~mm}$ (Quinto \& Santos 2005)

\section{Discussion}

Mangroves dominate one-fourth of the world's coastlines and comprised a total land area of about 181,000 km² (Thatoi et al. 2013). Considering their wide abundance, mangrove plants have been morphologically and physiologically adapted to extreme habitats of changing salinity, high temperature, tidal inundation, high wind velocity and faunal competition (Guerrero et al. 2018, Latha \& Mitra 2004). Interestingly, mangrove-associated fungi, known as the second largest ecological group of marine-derived fungi, promote the survival of their plant hosts under extreme environmental conditions through long term plant-fungi interactions (Zhou et al. 2018). As a result of such interactions, mangrove fungi were able to produce unique and diverse natural products. For several years, mangrove fungi attracted researchers across the globe due to its bioactive secondary metabolites, which could be target compounds in drug discovery, particularly in producing antibiotics, antidiabetic, antiviral, anti-inflammatory, anticancer, antioxidant and immunosuppressive and therapeutic agents (Thatoi et al. 2013). Mangrove-associated fungi have also been reported for their applications in bioremediation (Torres \& dela Cruz 2013).

Several studies have previously reported fungal endophytes associated with terrestrial plants collected in the Philippines, e.g. Canarium ovatum (Torres \& dela Cruz 2015), Ficus species (Solis et al. 2015, 2016), Pandanus amaryllifolius (Bungihan et al. 2011, 2013), and even from medicinal plants (Eskandarighadikolaii et al. 2015). In this study, 628 mangrove leaf endophytic fungi (MLEF) belonging to 20 different morphospecies were recorded from mangrove hosts collected from the provinces of Zambales, Batangas, Cavite, and Quezon in Luzon Island. The MLEF belonged to the genera Aspergillus, Cladosporium, Colletotrichum, Fusarium, Nigrospora, Penicillium, Pestalotiopsis, Phialophora and Trichoderma, with species capable of growth in culture media with marine salts (Table 2, Fig. 1). In addition, two morphospecies were not identified and one species was designated only as mycelia sterilia since the organism failed to produce any spores in vitro. Such high number of MLEF is not surprising, since, in general, leaves have a more diverse fungal endophytic community as compared to other parts of the plants (Hamzah et al. 2018). Cultivating the MLEF in PDA with and without marine salt revealed that most of the MLEF grew significantly better in the presence of marine salt, further supporting their adaptability to the marine environment (Fig. 1). Though the fungal strains were isolated from mangroves which are known halophytes, the isolated endophytic fungi belonged to known terrestrial fungal taxa. This was also observed by Kumaresan \& Suryanarayanan (2001) and Tariq et al. (2006), in which common terrestrial fungal taxa, including those belonging to the genera Alternaria, Aspergillus, Colletotrichum, Cladosporium, Fusarium, Penicillium and Trichoderma, were isolated from mangrove leaves, roots, and stems collected in India. However, obligate marine fungi, e.g. Cirrenalia pygmea, Cumulospora marine, Lulworthia sp., L. grandispora, Trichocladium alopallonellum and Zalerion maritimum, were also reported from the roots of mangroves (Ananda \& Sridhar 2002, Maria \& Sridhar 2003). In contrast, no obligate marine fungi were isolated from the collected mangrove leaves in this study. Spatafora et al. (1998) supported 
via molecular evidence the linkages between terrestrial fungi and the marine ascomycetes. The study proved that marine organisms, more specifically marine fungi, can trace their ancestors back to terrestrial organisms. In addition, plants such as mangroves survive in the ecotone between terrestrial and marine ecosystems (Rajamani et al. 2018). It is therefore not surprising to isolate terrestrial fungal genera from substrates collected in marine waters. Solis et al. (2010) and Notarte et al. (2017) also isolated marine-derived fungi from seaweeds belonging to known terrestrial fungal genera which exhibited better growth on culture medium with marine salts.

Endophytic fungi are known to be good sources of numerous bioactive secondary metabolites with antimicrobial activities (Leylaie \& Zafari 2018). Among the promising endophytes are the mangrove-associated fungi that produced novel compounds such as the trihydroxybenzene lactone cytosporone B that conferred antifungal activities against Aspergillus niger, Trichoderma sp. and Fusarium sp. (Xu et al. 2005) and the meroterpenes guignardones A and B that showed inhibitory activity against methicillin-resistant $S$. aureus (Mei et al. 2012). In the study of Silva et al. (2011), 34 ethyl acetate crude extracts of 70 strains of mangrove-associated fungi isolated from Laguncularia racemosa also showed to be active against a variety of pathogenic bacteria. Furthermore, the compounds chloropreussomerins A and B, isolated from the mangrove fungus Lasiodiplodia theobromae, were reported as effective antibacterial agent (Chen et al. 2016). In this study, 17 MLEF were selected and assayed for their antibacterial properties. Of the 17 MLEF, four isolates were found to be very active against $S$. aureus, while eight MLEF exhibited promising activity against $M$. luteus (Table 3). The bioactive MLEF were found to be belonging to the genera Cladosporium, Phialophora and Penicillium. Most of the MLEF were either partially active or inactive against the gram-negative bacteria $K$. oxytoca and P. aeruginosa. Similar results were also observed in the study of Maria et al. (2005) where little to no bioactivity was observed of their mangrove endophytic fungi against a gram-negative pathogen. However, their study also showed that the submerged state fermentation-derived extracts were active to partially active against various gram-positive bacteria. Comparing the results of this study and that of Maria et al. (2005), the metabolites from the mangrove fungal endophytes showed to favorably target the gram-positive bacteria as opposed to the gram-negative bacteria. Although in this study the bioactive MLEF, Cladosporium, Phialophora and Penicillium, were identified as fungal genera with known antibiotic activities, it is interesting to note that these were isolated from marine substrata, and thus, the metabolites may be different from their terrestrial counterparts. In fact, novel compounds have been isolated from these typical fungal genera of marine origin, including the antibacterial and antifungal polyketide malettinin E from Cladosporium (Silber et al. 2014) and the Penicilliumderived aromatic butenolides eutypoids B-E that inhibited glycogen synthase kinase-3 $\beta$, a target for the treatment of diabetes 2 (Schulz et al. 2011). Despite the isolation of these novel molecules, marine-derived fungi include mangrove-associated fungi remained to be an underrepresented sources of new natural products and, therefore, screening further these microbes, especially the mangrove fungal endophytes, for biological activities is highly encouraging (Imhoff 2016).

\section{Acknowledgements}

The authors would like to thank the University of Santo Tomas - Research Center for the Natural and Applied Sciences for the laboratory facility and KAA Santiago for technical assistance. CSP Ramirez would also like to acknowledge the Department of Science and Technology-Science Education Institute for the graduate scholarship and thesis grant.

\section{References}

Ananda K, Sridhar KR. 2002 - Diversity of endophytic fungi in the roots of mangrove species on the west coast of India. Canadian Journal of Microbiology 48, 871-878.

Doi: 10.1139/w02-080

Apurillo CCS, Cai L, dela Cruz TEE. 2019 - Diversity and bioactivities of mangrove fungal endophytes from Leyte and Samar, Philippines. Philippine Science Letters 12, 33-48. 
Bungihan ME, Tan MA, Kitajima M, Kogure N et al. 2011 - Bioactive metabolites of Diaporthe sp. P133, an endophytic fungus isolated from Pandanus amaryllifolius. Journal of Natural Medicines 65, 606-609. Doi: 10.1007/s11418-011-0518-x

Bungihan ME, Nonato MG, Draeger S, Franzblau S, dela Cruz TEE. 2013 - Antimicrobial and antioxidant activities of fungal leaf endophytes associated with Pandanus amaryllifolius Roxb.. Philippine Science Letters 6 (2), 128-137.

Calcul L, Waterman C, Ma WS, Lebar MD et al. 2013 - Screening mangrove endophytic fungi for antimalarial natural products. Marine Drugs 11, 5036-5050. Doi: 10.3390/md11125036

Calumpong HP, Meñez EG. 1997 - Field guide to the common mangroves, seagrasses, and algae of the Philippines. Makati City, Philippines, Bookmark.

Chen S, Chen D, Cai R, Cui H et al. 2016 - Cytotoxic and antibacterial preussomerins from the mangrove endophytic fungus Lasiodiplodia theobromae ZJ-HQ1. Journal of Natural Products 79(9), 2397-2402. Doi: 10.1021/acs.jnatprod.6b00639.

Deshmukh SK, Gupta MK, Prakash V, Sudhakara Reddy M. 2018 - Mangrove-associated fungi: A novel source of potential anticancer compounds. Journal of Fungi 4(3), 101.

Doi: 10.3390/jof4030101

Devi P, Rodrigues C, Naik CG, D’souza L. 2012 - Isolation and characterization of antibacterial compound from a mangrove-endophytic fungus, Penicillium chrysogenum MTCC 5108. Indian Journal of Microbiology 52, 617-623. Doi: 10.1007/s12088-012-0277-8

Eskandarighadikolaii S, dela Cruz TE, Bungihan M. 2015 - Antioxidant properties of fungal endophytes associated with the three medicinal plants Gliricidia sepium, Canna indica, and Gardenia jasminoides. Journal of Scientific Research and Reports 6(3), 217-226.

Doi: 10.9734/JSRR/2015/16272

Guerrero JJG, General MA, Serrano JE. 2018 - Culturable foliar fungal endophytes of mangrove species in Bicol Region, Philippines. Philippine Journal of Science 147(4), 563-574.

Hamzah TNT, Lee SY, Hidayat A, Terhem R et al. 2018 - Diversity and characterization of endophytic fungi isolated from the tropical mangrove species, Rhizophora mucronata, and identification of potential antagonists against the soil-borne fungus, Fusarium solani. Frontiers in Microbiology 9, 1707. Doi: 10.3389/fmicb.2018.01707

Henrici AT. 1930 - Molds, Yeast and Actinomycetes. New York, John \& Wiley \& Sons, Inc.

Imhoff JF. 2016 - Natural products from marine fungi - still an underrepresented resource. Marine Drugs 14, 1-19. Doi: 10.3390/md14010019

Kumaresan V, Suryanarayanan TS. 2001 - Occurrence and distribution of endophytic fungi in a mangrove community. Mycological Research 105(11), 1388-1391.

Doi: 10.1017/S0953756201004841

Latha R, Mitra S. 2004 - Mangrove fungi in India. Current Science 86(12), 1586-1587.

Lavadia MGB, Dagamac NHA, dela Cruz TEE. 2017 - Diversity and biofilm inhibition activities of algicolous fungi collected from two remote islands of the Philippine Archipelago. Current Research in Environmental \& Applied Mycology 7(4), 309-321.

Leylaie S, Zafari D. 2018 - Antiproliferative and antimicrobial activities of secondary metabolites and phylogenetic study of endophytic Trichoderma species from Vinca plants. Frontiers in Microbiology 9, 1484. Doi: 10.3389/fmicb.2018.01484

Maria GL, Sridhar KR. 2003 - Endophytic fungal assemblages of two halophytes from West Coast mangrove habitats, India. Czechoslovakian Mycology 53, 241-251.

Maria GL, Sridhar KR, Raviraja NS. 2005 - Antimicrobial and enzyme activity of mangrove endophytic fungi of southwest coast of India. Journal of Agricultural Technology 1, 67-80.

Mei WL, Zheng BO, Zhao YX, Zhong HM et al. 2012 - Meroterpenes from endophytic fungus a1 of mangrove plant Scyphiphora hydrophyllacea. Marine Drugs 10, 1993-2001.

Doi: 10.3390/md10091993

Moron LS, Lim YW, dela Cruz TEE. 2018 - Antimicrobial activities of crude culture extracts from mangrove fungal endophytes collected in Luzon Island, Philippines. Philippine Science Letters 11, 28-36. 
Notarte KI, Nakao Y, Yaguchi T, Bungihan M et al. 2017 - Trypanocidal activity, cytotoxicity and histone modifications induced by malformin $\mathrm{a}_{1}$ isolated from the marine-derived fungus Aspergillus tubingensis IFM 63452. Mycosphere 8, 111-120.

Notarte KI, Yaguchi T, Suganuma K, dela Cruz TE. 2018 - Antibacterial, cytotoxic and trypanocidal activities of marine-derived fungi isolated from Philippine macroalgae and seagrasses. Acta Botanica Croatica 77 (2), 141-151. Doi: 10.2478/botcro-2018-0016

Primavera JH. 2000 - Development and conservation of Philippine mangroves: institutional issues. Ecological Economics 35(1), 91-106. Doi: 10.1016/S0921-8009(00)00170-1

Primavera JH. 2009 - Field guide to Philippine mangroves. SEAFDEC, Manila.

Quinto E, Santos M. 2005 - Microbiology. In: BQ Guevarra (ed), A guidebook to plant screening: phytochemical and biological. University of Santo Tomas Publishing House, Manila, pp. 63100.

Rajamani T, Suryanarayanan TS, Murali TS, Thirunavukkarasu N. 2018 - Distribution and diversity of foliar endophytic fungi in mangroves of Andaman Islands, India. Fungal Ecology 36, 109-116. Doi: 10.1016/j.funeco.2018.09.007

Samson RA, Houbraken J, Thrane U, Frisvad JC, Andersen B. 2010 - Food and indoor fungi. Centraalbureau voor Schimmelcultures, Netherlands.

Schulz B, Draeger S, dela Cruz TEE, Rheinheimer J et al. 2008 - Screening strategies for obtaining novel, biologically active fungal secondary metabolites from marine habitats. Botanica Marina 51, 169-234. Doi: 10.1515/BOT.2008.029

Schulz D, Ohlendorf B, Zinecker H, Schmaljohann R, Imhoff JF. 2011 - Eutypoids b-e produced by a Penicillium sp. strain from the North Sea. Journal of Natural Products 74(1), 99-101. Doi: 10.1021/np100633k

Silber J, Ohlendorf B, Labes A, Storjohann AW et al. 2014 - Malettinin e, an antibacterial and antifungal tropolone produced by a marine Cladosporium strain. Frontiers in Marine Science 1(35), 1-6. Doi: 10.3389/fmars.2014.00035

Silva MRO, Almeida AC, Arruda FVF, Gusmão N. 2011 - Endophytic fungi from Brazilian mangrove plant Laguncularia racemosa (L.) Gaertn. (Combretaceae): their antimicrobial potential. In: Mendez-Vilas A (ed), Science against microbial pathogens: communicating current research and technological advances. Formatex Research Center, Badajoz, pp. 1260 1266.

Solis MJ, Draeger S, dela Cruz TE. 2010 - Fungi from Kappaphycus alvarezii and K. striatum: biodiversity, taxonomy and ice-ice disease induction. Botanica Marina 53, 587-594.

Solis MJL, Yurkov A, dela Cruz TE, Unterseher M. 2015 - Leaf-inhabiting endophytic yeasts are abundant but unevenly distributed in three Ficus species from botanical garden greenhouses in Germany. Mycological Progress 14(1), 1019. Doi: 10.1007/s11557-014-1019-6

Solis MJL, dela Cruz TE, Schnittler M, Unterseher M. 2016 - The diverse community of leafinhabiting fungal endophytes from Philippine natural forests reflects phylogenetic patterns of their host plant species Ficus benjamina, F. elastica and F. religiosa. Mycoscience 57(2), 96106. Doi: $10.1016 /$ j.myc.2015.10.002

Spatafora JW, Volkmann-Kohlmeyer B, Kohlymeyer J. 1998 - Independent terrestrial origins of the Halosphaeriales (marine Ascomycota). American Journal of Botany 85(11), 1569-1580. Doi: $10.2307 / 2446483$.

Tan MA, dela Cruz TE, Apurillo CCS, Proksch P. 2015 - Chemical constituents from a Philippine mangrove endophytic fungi Phyllosticta sp. Der Pharma Chemica 7(2), 43-45.

Tariq M, Dawar S, Mehdi FS. 2006 - Occurrence of fungi on mangrove plants. Pakistan Journal of Botany 38(4), 1293-1299.

Thatoi H, Behera BC, Mishra RR. 2013 - Ecological role and biotechnological potential of mangrove fungi: a review. Mycology 4(1), 54-71. Doi: 10.1080/21501203.2013.785448

Toofanee SB, Dulymamode R. 2002 - Fungal endophytes associated with Cordemoya integrifolia. Fungal Diversity 11, 169-175.

Torres JMO, dela Cruz TEE. 2013 - Production of xylanases by mangrove fungi from the 
Philippines and their application in enzymatic pretreatment of recycled paper pulps. World Journal of Microbiology and Biotechnology 29(4), 645-655.

Doi: $10.1007 / \mathrm{s} 11274-012-1220-1$

Torres JMO, dela Cruz TEE. 2015 - Antibacterial activities of fungal endophytes associated with the Philippine endemic tree, Canarium ovatum Engl. Mycosphere 4(2), 363-454.

Xu QY, Huang Y, Zheng ZH, Song S. 2005 - Purification, elucidation and activities study of cytosporone b. Journal of Xiamen University Natural Science 44(3), 425-428.

Yu G, Zhou G, Zhu M, Wang W et al. 2016 - Neosartoryadins a and b, fumiquinazoline alkaloids from a mangrove-derived fungus Neosartorya udagawae HDN13-313. Organic Letters 18(2), 244-247. Doi: 10.1021/acs.orglett.5b02964

Zhou J, Diao X, Wang T, Chen G et al. 2018 - Phylogenetic diversity and antioxidant activities of culturable fungal endophytes associated with the mangrove species Rhizophora stylosa and $R$. mucronate in the South China Sea. PLoS One 13(6), e0197359.

Doi: 10.1371/journal.pone.0197359 